\title{
Phytoremediation of Latex Effluent by Constructed Wetland Technology
}

\author{
Dipu Sukumaran ${ }^{1, *}$, Anju Anilkumar², Salom Gnana Thanga ${ }^{2}$ \\ ${ }^{1}$ Central Pollution Control Board Zonal Office- Kolkata, Southend Conclave India \\ ${ }^{2}$ Department of Environmental Sciences, University of Kerala, Kerala, India \\ *Corresponding author: dipudr@rediffmail.com
}

Received August 15, 2013; Revised October 16, 2013; Accepted November 12, 2013

\begin{abstract}
The present study is an attempt to have a comparative assessment of the efficiency of aquatic weeds like Typha latifolia, Eichhornia crassipes, Pistia stratiotes to treat the effluents from latex factory, in constructed wetlands. Ammonification of field latex, acid coagulation of skim latex and various chemical treatments during the production process of various products were found to be responsible for the high concentration of pollutants in this factory effluent. Phytoremediation for fifteen days by constructed wetland technology reduced the chemical oxygen demand, biochemical oxygen demand, $\mathrm{pH}$, total solids of the effluent considerably.
\end{abstract}

Keywords: phytoremediation, natural rubber waste water, chemical oxygen demand, constructed wetland technology

Cite This Article: Dipu Sukumaran, Anju Anilkumar, and Salom Gnana Thanga, "Phytoremediation of Latex Effluent by Constructed Wetland Technology.” Applied Ecology and Environmental Sciences 1, no. 6 (2013): 104-109. doi: 10.12691/aees-1-6-1.

\section{Introduction}

Phytoremediation is defined as the use of plants as well as micro organisms of the rhizosphere to remove or render harmless pollutants from contaminated sites [1,2]. Soils frequently receive a wide range of contaminants from industrial activities, sewage sludge disposal, metal processing, and energy production, and in many cases remediation is both expensive and intrusive to the ecosystem. Phytoremediation makes use of plants and plant processes to remove, degrade, or render harmless hazardous materials present in the soil or groundwater. This emerging technology may offer a cost-effective, nonintrusive, and safe alternative to conventional soil cleanup techniques by using the ability of certain tree, shrub, and grass species to remove, degrade, or immobilize harmful chemicals from the soil.

The most applicable technology using phytoremediation strategy is constructed wetland technology (CWs). Besides water quality improvement and energy savings, CWs have other features related to the environmental protection such as promoting biodiversity, providing habitat for wetland organisms and wildlife (e.g. birds and reptiles in large systems), serving climatic (e.g. less $\mathrm{CO}_{2}$ production, [3]; hydrological functions, heavy metal bioaccumulation and biomethylation [4].

Phytoremediation can also occur via the degradative activity of rhizosphere micro organisms. The rhizosphere is operationally defined as the "soil-root interfacial area" and relatively large numbers of diverse species of micro organisms live in association with plant roots. The word "rhizosphere" first introduced by Hiltner [5], the region immediately surrounding the root, describes the interaction between bacteria and the roots of plants. Micro organisms colonize and live within these areas and the degree of intimacy at which a micro organism interacts with a root varies in proportion to the distance from the root surface. The closer a microbe is to the root surface, the more its growth and behavior be influenced by plantreleased materials [6]. Root exudations are thought to have a stimulatory effect on rhizosphere microbes, which in turn, are purported to accelerate biodegradation in the rhizosphere $[7,8]$.

Alicia et al. [9] reported that the roots of some aquatic plants could retain both coarse and fine particulate organic materials present in water bodies supporting their growth. Plants sustain large microbial population in the rhizosphere by rhizo-deposition, root cap cells, which protect the root from abrasion, may be lost to the soil at a rate of 10000 cells per plant. In addition, root cells excrete mucigel, a gelatinous substance that is a lubricant for root penetration through the soil during growth and microbes in the root zone can help to solublise insoluble nutrients and recycle organically bound nutritive elements [10,11].

\section{Methodology}

\subsection{Experimental Setup}

The effluents from Hindustan Latex Ltd. (HLL), Kerala, India were used for the phytoremediation research purpose. Wastewater in this factory originates from washing of the centrifuge at the end of each operation, from coagulation milling sections and spill over from tanks and floor 
washings. Ammonification of field latex, acid coagulation of skim latex and various chemical treatments during the production process of various products were found to be responsible for the high concentration of pollutants in this factory effluent.

Approximately 10 liters of raw effluent from factory was brought to the laboratory in plastic containers and the experiments were set up in plastic craits. The plants used for the study was an emergent wetland plant Typha sp. and floating wetland macrophytes like Pistia sp. and Eichhornia sp. The experimental plants were initially subject to stabilization in tanks containing well water for one month for acclimatization. The base of the tank was filled with gravel and wetland soil up to three inches in height. Ten liters of the respective dilutions of the effluent were prepared and were transferred to plastic tubs. For each experimental set, two controls were maintained with ten liters of well water and 10 liters of effluent respectively.

For treatments, the respective plants which were maintained in the tanks were collected, cleaned and blotted. Approximately 250g each experimental plant used for the study, each occupying half of craits, were carefully introduced into the treatment containers. Duplicate of each experimental setup was maintained. $500 \mathrm{ml}$ each of water and effluent samples from the respective treatment sets were collected periodically for analyzing the changes in its physico-chemical characteristics. Water and plant samples (25g) were taken initially and subsequently with an interval of 5 days up to 15 days. Thus the analyses of water samples were carried out at four stages of treatment.

\subsection{Estimation of Physicochemical Parameters of the Effluents}

The effluent samples collected from the treatment sets were subjected to physico-chemical analysis following standard methods [12]. For testing statistical significance, student's t-test was used. Independent sample t-test was used for finding the mean difference of each parameter control with plants.

\section{Results}

\subsection{Treatment of Latex Effluent with Pistia sp.}

A decrease in $\mathrm{pH}$ was observed when HLL effluent was treated with Pistia sp. in constructed wetlands. The $\mathrm{pH}$ decreased steadily from 8.35 to 7.81 in the case of undiluted effluent and from 8.06 to 7.57 in diluted effluent. In well water control, a slight positive change was observed but in HLL control, a slight negative change was observed. Significant reduction was observed in turbidity after 15 days of treatment in both diluted and undiluted effluents $(p<0.05)$. In case of TDS also, a significant reduction $(\mathrm{p}<0.05)$ was noticed. But in the case of well water sample, the TS, TDS were found to increase with treatment.

BOD and COD showed drastic changes when the effluent was treated by this system. In undiluted effluent, the BOD reduced significantly $(\mathrm{p}<0.01)$ by 450 per cent from initial level after 15 days. When the effluent was diluted, BOD reduction was 800 per cent from the initial level after 15 days retention time. COD of undiluted effluent also showed significant reduction $(\mathrm{p}<0.01)$. The diluted effluent showed 604.54 per cent reduction (Table 1).

Table 1. Variation in physicochemical characteristics of HLL effluent treated with Pistia sp.

\begin{tabular}{|c|c|c|c|c|c|}
\hline Parameters analysed & Retention time & HLL control & Well water control & Diluted effluent & Undiluted effluent \\
\hline \multirow{5}{*}{$\mathrm{pH}$} & initial & 8.35 & 7.57 & 8.06 & 8.35 \\
\hline & $5 \mathrm{~d}$ & 8.32 & 7.41 & 8.01 & 8.09 \\
\hline & $10 \mathrm{~d}$ & 8.32 & 7.38 & 7.72 & 7.81 \\
\hline & $15 \mathrm{~d}$ & 8.27 & 7.62 & 7.57 & 7.71 \\
\hline & \%increase/decrease & -0.36 & +0.65 & -6.47 & -8.3 \\
\hline \multirow{5}{*}{$\begin{array}{l}\text { Turbidity } \\
\text { (NTU) }\end{array}$} & initial & 280 & 4 & 220 & 280 \\
\hline & $5 \mathrm{~d}$ & 276 & 9 & 188 & 224 \\
\hline & $10 \mathrm{~d}$ & 277 & 6 & 162 & 174 \\
\hline & $15 \mathrm{~d}$ & 268 & 5 & 106 & 162 \\
\hline & \%increase/decrease & -4.47 & +20 & -107.54 & -72.84 \\
\hline \multirow{5}{*}{ Total solids (ppm) } & initial & 286 & 18 & 156 & 286 \\
\hline & $5 \mathrm{~d}$ & 284 & 23 & 142 & 192 \\
\hline & $10 \mathrm{~d}$ & 281 & 22 & 135 & 186 \\
\hline & $15 \mathrm{~d}$ & 275 & 21 & 112 & 182 \\
\hline & \%increase/decrease & -4 & +14.2 & -39.28 & $-57.14(*)$ \\
\hline \multirow{5}{*}{$\begin{array}{l}\text { TDS } \\
\text { (ppm) }\end{array}$} & initial & 283.55 & 17.06 & 154.59 & 283.55 \\
\hline & $5 \mathrm{~d}$ & 281.57 & 16.88 & 140.14 & 189.44 \\
\hline & $10 \mathrm{~d}$ & 278.63 & 20.59 & 133.02 & 183.11 \\
\hline & $15 \mathrm{~d}$ & 272.68 & 19.14 & 109.79 & 178.54 \\
\hline & \%increase/decrease & -3.98 & +10.8 & -40.80 & -58.82 \\
\hline \multirow{5}{*}{$\begin{array}{l}\text { BOD } \\
\text { (ppm) }\end{array}$} & initial & 660 & 2.1 & 540 & 660 \\
\hline & $5 \mathrm{~d}$ & 648 & 2.2 & 280 & 380 \\
\hline & $10 \mathrm{~d}$ & 642 & 1.8 & 120 & 210 \\
\hline & $15 \mathrm{~d}$ & 635 & 1.2 & 60 & 120 \\
\hline & \%increase/decrease & -3.93 & -75 & $-800(* *)$ & $-450(* *)$ \\
\hline \multirow{5}{*}{$\begin{array}{l}\text { COD } \\
\text { (ppm) }\end{array}$} & initial & 1120 & 2.8 & 620 & 1120 \\
\hline & $5 \mathrm{~d}$ & 1118 & 2.4 & 285 & 562 \\
\hline & $10 \mathrm{~d}$ & 1110 & 1.8 & 122 & 261 \\
\hline & $15 \mathrm{~d}$ & 1102 & 1.8 & 88 & 185 \\
\hline & \%increase/decrease & -1.63 & -55.5 & $-604.54(* *)$ & $-505.41(* *)$ \\
\hline
\end{tabular}




\subsection{Treatment of Latex Effluent with Eichhornia sp.}

When treated with Eichhornia sp. based CWs, $\mathrm{pH}$ of HLL effluent was found to decrease i.e. from 8.35 to 7.78 and from 8.06 to 7.68 in undiluted and diluted effluent respectively after 15 days of retention period. However, in TTP control, the $\mathrm{pH}$ was found to decrease slightly. The reduction in turbidity was high in diluted effluent (115.68 per cent). In well water the turbidity was found to increase slightly (20 per cent). Total solids showed a pronounced reduction in both diluted and undiluted effluent $(\mathrm{p}<0.05)$ in the Eichhornia sp. based CWs. The percentage reduction for sodium was more with undiluted effluent. BOD (500 per cent) and COD (515.3 per cent) of undiluted effluent reduced drastically. The reduction in BOD and COD of undiluted effluent was statistically significant at 1 per cent level (Table 2).

Table 2. Variation in physicochemical characteristics of HLL effluent treated with Eichhornia sp.

\begin{tabular}{|c|c|c|c|c|c|}
\hline Parameters analysed & Retention time & HLL control & Well water control & Diluted effluent & Undiluted effluent \\
\hline \multirow{5}{*}{$\mathrm{pH}$} & initial & 8.35 & 7.57 & 8.06 & 8.35 \\
\hline & $5 \mathrm{~d}$ & 8.32 & 7.41 & 8.02 & 8.12 \\
\hline & $10 \mathrm{~d}$ & 8.32 & 7.38 & 7.86 & 7.98 \\
\hline & $15 \mathrm{~d}$ & 8.27 & 7.62 & 7.68 & 7.78 \\
\hline & \%increase/decrease & -0.36 & +0.65 & -4.94 & -7.32 \\
\hline \multirow{5}{*}{$\begin{array}{l}\text { Turbidity } \\
\text { (NTU) }\end{array}$} & initial & 280 & 4 & 220 & 280 \\
\hline & $5 \mathrm{~d}$ & 276 & 9 & 182 & 212 \\
\hline & $10 \mathrm{~d}$ & 277 & 6 & 152 & 186 \\
\hline & $15 \mathrm{~d}$ & 268 & 5 & 102 & 156 \\
\hline & \%increase/decrease & -4.47 & +20 & -115.68 & $-79.4(*)$ \\
\hline \multirow{5}{*}{ Total solids (ppm) } & initial & 286 & 18 & 156 & 286 \\
\hline & $5 \mathrm{~d}$ & 284 & 23 & 143 & 188 \\
\hline & $10 \mathrm{~d}$ & 281 & 22 & 127 & 173 \\
\hline & $15 \mathrm{~d}$ & 275 & 21 & 102 & 162 \\
\hline & \%increase/decrease & -4 & +14.2 & -52.9 & $-76.5(*)$ \\
\hline \multirow{5}{*}{$\begin{array}{l}\text { TDS } \\
\text { (ppm) }\end{array}$} & initial & 283.55 & 17.06 & 154.59 & 283.55 \\
\hline & $5 \mathrm{~d}$ & 281.57 & 16.88 & 141.2 & 186.09 \\
\hline & $10 \mathrm{~d}$ & 278.63 & 20.59 & 125.34 & 170.35 \\
\hline & $15 \mathrm{~d}$ & 272.68 & 19.14 & 99.78 & 158.31 \\
\hline & \%increase/decrease & -3.98 & +10.8 & -54.93 & -79.11 \\
\hline \multirow{5}{*}{$\begin{array}{l}\text { BOD } \\
\text { (ppm) }\end{array}$} & initial & 660 & 2.1 & 540 & 660 \\
\hline & $5 \mathrm{~d}$ & 648 & 2.2 & 270 & 360 \\
\hline & $10 \mathrm{~d}$ & 642 & 1.8 & 160 & 190 \\
\hline & $15 \mathrm{~d}$ & 635 & 1.2 & 90 & 110 \\
\hline & \%increase/decrease & -3.93 & -75 & $-500(* *)$ & $-500(* *)$ \\
\hline \multirow{5}{*}{$\begin{array}{l}\text { COD } \\
\text { (ppm) }\end{array}$} & initial & 1120 & 2.8 & 620 & 1120 \\
\hline & $5 \mathrm{~d}$ & 1118 & 2.4 & 322 & 685 \\
\hline & $10 \mathrm{~d}$ & 1110 & 1.8 & 142 & 362 \\
\hline & $15 \mathrm{~d}$ & 1102 & 1.8 & 66 & 182 \\
\hline & \%increase/decrease & -1.63 & -55.5 & $-839.39(* *)$ & $-515.3(* *)$ \\
\hline
\end{tabular}

$(*)$ indicates significance at $5 \%$ level

$(* *)$ indicates significance at $1 \%$ level

\subsection{Treatment of Latex Effluent with Typha sp.}

The initial $\mathrm{pH}$ of the undiluted effluent was 8.35. It decreased at a regular interval to 7.58 after 15 days of treatment. In the case of diluted effluent, the percentage decrease was 11.43. However, the $\mathrm{pH}$ of well water control increased ( 0.65 per cent). Turbidity showed a decreasing trend both in undiluted $(\mathrm{p}<0.05)$ and diluted effluent, after 15 days of treatment. The TS of undiluted effluent was 286 ppm, which then decreased considerably to $158 \mathrm{ppm}$ after 15 days of treatment $(\mathrm{p}<0.05)$. In diluted effluent the initial TS was 156 ppm and decreased to 122 ppm after 15 days of treatment and the reduction was 27.86 per cent. The TDS of the undiluted effluent was 283.55 ppm, which then decreased to 155.56 ppm after 15 days of treatment.

BOD of the undiluted effluent decreased after 15 days of treatment from $660 \mathrm{ppm}$ to $98 \mathrm{ppm}$. In diluted effluent the percentage decrease was 900 . In case of COD, the undiluted effluent had an initial value of $1120 \mathrm{ppm}$ and then decreased considerably to $136 \mathrm{ppm}(\mathrm{p}<0.01)$. In diluted effluent, the COD value decreased up to 545.83 per cent. The COD of both well water and effluent controls also decreased slightly (Table 3 ). 
Table 3. Variation in physicochemical characteristics of HLL effluent treated with Typha sp.

\begin{tabular}{|c|c|c|c|c|c|}
\hline Parameters analysed & Retention time & HLL control & Well water control & Diluted effluent & Undiluted effluent \\
\hline \multirow{5}{*}{$\mathrm{pH}$} & initial & 8.35 & 7.57 & 8.06 & 8.35 \\
\hline & $5 \mathrm{~d}$ & 8.32 & 7.41 & 8.04 & 8.24 \\
\hline & $10 \mathrm{~d}$ & 8.32 & 7.38 & 7.66 & 7.94 \\
\hline & $15 \mathrm{~d}$ & 8.27 & 7.62 & 7.52 & 7.58 \\
\hline & \%increase/decrease & -0.36 & +0.65 & -11.43 & -10.15 \\
\hline \multirow{5}{*}{$\begin{array}{l}\text { Turbidity } \\
\text { (NTU) }\end{array}$} & initial & 280 & 4 & 220 & 280 \\
\hline & $5 \mathrm{~d}$ & 276 & 9 & 184 & 198 \\
\hline & $10 \mathrm{~d}$ & 277 & 6 & 161 & 176 \\
\hline & $15 \mathrm{~d}$ & 268 & 5 & 121 & 146 \\
\hline & \%increase/decrease & -4.47 & +20 & -81.81 & $-91.78(*)$ \\
\hline \multirow{5}{*}{ Total solids (ppm) } & initial & 286 & 18 & 156 & 286 \\
\hline & $5 \mathrm{~d}$ & 284 & 23 & 148 & 202 \\
\hline & $10 \mathrm{~d}$ & 281 & 22 & 130 & 182 \\
\hline & $15 \mathrm{~d}$ & 275 & 21 & 122 & 158 \\
\hline & \%increase/decrease & -4 & +14.2 & -27.86 & $-81.01(*)$ \\
\hline \multirow{5}{*}{$\begin{array}{l}\text { TDS } \\
\text { (ppm) }\end{array}$} & initial & 283.55 & 17.06 & 154.59 & 283.55 \\
\hline & $5 \mathrm{~d}$ & 281.57 & 16.88 & 146.68 & 199.65 \\
\hline & $10 \mathrm{~d}$ & 278.63 & 20.59 & 128.71 & 179.69 \\
\hline & $15 \mathrm{~d}$ & 272.68 & 19.14 & 120.46 & 155.56 \\
\hline & \%increase/decrease & -3.98 & +10.8 & -28.3 & -82.27 \\
\hline \multirow{5}{*}{$\begin{array}{l}\text { BOD } \\
(\mathrm{ppm})\end{array}$} & initial & 660 & 2.1 & 540 & 660 \\
\hline & $5 \mathrm{~d}$ & 648 & 2.2 & 240 & 320 \\
\hline & $10 \mathrm{~d}$ & 642 & 1.8 & 130 & 198 \\
\hline & $15 \mathrm{~d}$ & 635 & 1.2 & 54 & 98 \\
\hline & \%increase/decrease & -3.93 & -75 & $-900(* *)$ & $-573.46(* *)$ \\
\hline \multirow{5}{*}{$\begin{array}{l}\text { COD } \\
(\mathrm{ppm})\end{array}$} & initial & 1120 & 2.8 & 620 & 1120 \\
\hline & $5 \mathrm{~d}$ & 1118 & 2.4 & 320 & 482 \\
\hline & $10 \mathrm{~d}$ & 1110 & 1.8 & 240 & 241 \\
\hline & $15 \mathrm{~d}$ & 1102 & 1.8 & 96 & 136 \\
\hline & \%increase/decrease & -1.63 & -55.5 & $-545.83(* *)$ & $-723.52(* *)$ \\
\hline
\end{tabular}

(*) indicates significance at $5 \%$ level

$(* *)$ indicates significance at $1 \%$ level

\section{Discussion}

$\mathrm{pH}$ seems to be the most important parameter in the biosorptive process: it affects the solution chemistry of the metals, the activity of the functional groups in the biomass and the competition of metallic ions [13]. The $\mathrm{pH}$ of the water samples from the control and treatment sets of Eichhornia sp., Pistia sp., Typha sp. were brought to the neutral range after treatment with the respective weeds. The $\mathrm{pH}$ of raw effluents used for the present study was found to be alkaline. The $\mathrm{pH}$ was reduced from alkaline to nearly neutral in all cases studied by treatment with aquatic macrophytes. Abioye [14] and Mahmood et al. [15] earlier reported similar results. It could be interpreted that the reduction in $\mathrm{pH}$ is due to absorption of pollutants by plants [15].

An increase in conductivity was observed in the diluted and undiluted effluents of HLL. This might be due to the release of ions by the plants in the wetland [16]. In this study also a very high reduction in turbidity was noticed with all the experimental plants. In HLL effluent, the turbidity of diluted effluent was highly reduced than that of the undiluted effluent. Alicia et al. [9] reported that the roots of some aquatic plants can retain both coarse and fine particulate organic materials present in water bodies supporting their growth. This was mainly achieved through the electrical charges associated with the root hairs, which reacts with the opposite charges on colloidal particles. The reduction in total solids of effluent samples treated by the aquatic macrophytes in the present study could be attributed to this reason. Gudekar and Trivedi [17] reported 59.54 per cent reduction of turbidity in treatment of engineering industry waste with water hyacinth.

The total solids of all the effluents were significantly reduced with all the plants after the treatment period. The maximum reduction was with Typha sp. In the effluent control also values of total solids showed a similar trend of reduction but the reduction was very low. But in the case of well water control, TS increased slightly. Ghaly et al. [18] reported 54.7 per cent to 91.0 per cent reduction in total solids in aquaculture waste treated with aquatic macrophytes in 12 days. The reduction of TS was due to the retaining of coarse and fine particulate organic materials present in water bodies supporting their growth by the root system [9].

Total dissolved solids measurements are often used to express the degree of contamination or amount of impurities in water and wastewater. A wide variety of inorganic ions and organic compounds, many of which may not be considered as contaminants, contribute to the sum total of dissolved solids. HLL effluent, on treatment with Typha sp. based CWs; there was a considerable reduction (82.27 per cent) in undiluted effluent. Groudev et al. [19] observed reduction of total dissolved solids from $2620 \mathrm{ppm}$ to $1230 \mathrm{ppm}$ in treatment of acid mine drainage from an uranium deposit by means of a natural wetland. However a slight removal of TDS was observed by Wirojanagud et al. [20] in pulp and paper industrial wastewater.

Organic matter contains approximately 45 to 50 per cent carbon, which is utilized by a wide array of micro 
organisms as a source of energy. A large number of these micro organisms consume oxygen to break down organic carbon to carbon dioxide, a process that provides energy for growth. Therefore, the release of excessive amounts of organic carbon to surface waters can result in a significant depletion of $\mathrm{O}_{2}$ and subsequent mortality of fish and other $\mathrm{O}_{2}$ dependent aquatic or marine organisms. Marked reduction in BOD was noticed with water samples from various treatment sets. Different effluent samples from Eichhornia sp., Pistia sp., Typha sp. showed marked reduction in BOD. Santos et al. [21] reported reduction of 90.7 per cent BOD in 5 days with a high organic load stabilization pond using water hyacinth. An evaluation of ten systems utilizing surface flow wetlands by Conley et al. [22] showed BOD removal rates ranged from 64 per cent to 96 per cent. Tegegne et al. [23] and Kirzhner et al. [16] noticed significance decrease in the concentration of BOD when the effluents from various industries were treated with constructed wetlands.

HLL effluent had BOD of $660 \mathrm{ppm}$ in the undiluted sample. On treatment with Typha sp. based CWs, the BOD value was reduced at a maximum level to $98 \mathrm{ppm}$. Tripathi and Shukla [24] reported 96.9 per cent reduction in BOD using water hyacinth and algae for sewage wastewater. Recent studies by Adeola et al. [25] reported significant reductions in the biochemical oxygen demand throughout the system with levels decreasing by up to 76.7 per cent across the constructed wetland cells. Gudekar and Trivedi [17] reported 63.41 per cent reduction in BOD with 4 days treatment and 89.13 per cent reduction in BOD with 2 days treatment using effluent from engineering industry waste. Sharma and Sharma [25] noticed a reduction of 70 per cent COD and 72 per cent BOD after 10 days of treatment with paper mill effluent in phytoremediation. Kirzhner et al. [16] working in phytoremediation reported that the BOD of industrial effluents was removed by 65 per cent to 70 per cent after four days of retention period by floating macrophytes.

Different effluent samples after treatment from Eichhornia sp., Pistia sp., Typha sp. showed marked reduction in chemical oxygen demand. In case of undiluted HLL effluent, COD (1120 ppm) was reduced maximum by Typha sp. based CWs. Regarding diluted HLL effluent which had 620 ppm of COD, the maximum reduction was with Eichhornia sp. based CWs. Zimmels et al. [26] noticed 360 per cent reduction in COD in a pilot study with Eichhornia crassipes and Pistia stratiotes for treatment of urban sewage in Israel. Zhang et al. [27] reported that the efficiency of COD removal varied a lot for various species to different contaminants. Treatment of textile dye using anaerobic baffled reactor by wetland plants removed 70-90 per cent COD [28,29]. Tegegne et al. [23] noticed significance difference (56.0 per cent to 91.5 per cent) in the concentration of COD when the effluents from various industries were treated with wetlands. The average overall treatment efficiency for COD removal in these systems was strictly in agreement with other literature results $[30,31])$.

The reduction in BOD and COD can be attributed to many reasons. Aquatic plants have the unique feature of transporting oxygen from the aerial plant portions to the submerged parts of the plant and the oxygen transported by aquatic plants significantly increase the sub canopy oxygen content of the water [32]. Reddy and DeBusk [33] reported that oxygen transfer by aquatic plants in to the root zone plays a significant role in supporting the growth of aerobic bacteria in the root zone and subsequent degradation of waste water carbon [34]. Moreover, the higher suspended solids in the effluent samples may help in enhanced microbial activity as additional substrate on the roots of aquatic plants. The reduction in $\mathrm{pH}$ favoured microbial action to degrade BOD and COD in the wastewater.

\section{Conclusion}

This sustainable and inexpensive process is fast emerging as a viable alternative to conventional remediation methods, and will be most suitable for a developing countries Fast growing plants with high biomass and good metal uptake ability are needed. In most of the contaminated sites hardy, tolerant, weed species exist and phytoremediation through these and other nonedible species can restrict the contaminant from being introduced into the food web. From this study, the emergent plant Typha sp. based constructed wetland has proved as a promising technology for removing pollutants from latex industry effluents. Its rooted nature has favored increased rhizosphere activity, thereby enhancing nutrient and pollutant removal. Among the floating plants, Eichhornia sp. was found to be more effective for treatment of industrial effluent. The extensive root system and flourished biomass growth might have favored this.

\section{Acknowledgements}

The authors acknowledge with gratitude the help and support from Prof. \& Head Department of Environmental Sciences, University of Kerala. Thanks are also due to University Grants Commission, India for the financial support to complete the project.

\section{References}

[1] Lasat, M.M., "Phytoextraction of toxic metals: a review of biological mechanisms,” J. Environ. Qual., 31,109-129. 2002.

[2] Singh, O.V., Laban S., "Phytoremediation: an overview of metallic ion decontamination from soil,” Applied Microbiology and Biotechnology, 61, 405-412. 2003.

[3] Dixon, A., Simon, M., Burkitt, T., "Assessing the environmental impact of two options for small scale wastewater treatment: Comparing a reed bed and an aerated biological filter using a life cycle approach,” Ecological Engineering, 20, 297-308. 2003.

[4] Azaizeh, H., Salhani, N., Sebesvari, Z., Emons H., “The potential of rhizosphere microbes isolated from a constructed wetland to biomethylate selenium," Journal of Environmental Quality, 32, 55-62. 2003.

[5] Hiltner, L. "Uber neuere Erfahrungen und Probleme auf dem Gebiet der Bodenbakteriologie und unter besonderer Berucksichtigung der Grundungung and Brache," Arbeiten der Deutschen Landwirtschaftlichen Gesellschaft, 98, 59-78. 1904.

[6] Sadowsky, M.J., Schortemeyer, M., "Soil microbial responses to increased concentrations of atmospheric $\mathrm{CO}_{2}$," Global Change Biol., 3, 217-244. 1997.

[7] Nichols, T.D., Wolf, D.C., Rogers, H.B., Beyrouty C.A., Reynolds, C.M., "Rhizosphere microbial populations in contaminated soils," Water Air Soil Poll., 95, 165-178. 1997.

[8] Siciliano, S.D. and Germida J.J., "Mechanisms of Phytoremediation: Biochemical and Ecological Interactions 
between Plants and Bacteria,” Environmental Review, 6, 65-79. 1998.

[9] Alicia, P.D.N., Jaun, J.N., Orfeo, O., Cardigan, R., "Quantitative importance of particulate matter retention by the roots of Eichhornia crassipes in the Parana floodplains," Aquatic Botany, 47, 213-223. 1994.

[10] Jones, R., Sun, W., Tang, C.S., Robert, F.M., "Phytoremediation of petroleum hydrocarbons in tropical coastal soils. II. Microbial response to plant roots and contaminant," Environ. Sci. Pollut. Research, 11,340-346. 2004.

[11] Kirk, J., Klironomos, J., Lee, H., Trevors, J.T., "The effects of perennial ryegrass and alfalfa on microbial abundance and diversity in petroleum contaminated soil," Environ. Pollut. 133, 455-465. 2005.

[12] APHA. Standard method for examination of water and waste water (15 ${ }^{\text {th }}$ Edition). APHA, AWWA, Washington DC, 1995.

[13] Galun, M., "Removal of metal ions from aqueous solutions by Pencillium biomass: Kinetic and uptake parameters," Water, Air and Soil Pollution, 33, 359-371. 1987.

[14] Abioye, O.F., Phytoremediation of arsenic-contaminated soil and groundwater, PhD Thesis, University of Florida, 122-138. 2005.

[15] Mahmood, Q., Zheng, P., Islam E., Hayat, Y., Hassan, M. J., Jilani G., Jin. R.C., "Lab Scale Studies on Water Hyacinth (Eichhornia crassipes Marts Solms) for Bio treatment of Textile Wastewater," Caspian J. Env. Sci., 3(2), 83-88. 2005.

[16] Kirzhner, F., Zimmels, Y., Gafni, A., "Effect of evapotranspiration on the salinity of wastewater treated by aquatic plants." Reviews on environmental health, 23(2): pp. 149-66. 2008.

[17] Gudekar, V.R. and Trivedi, R.K. "Effect of surface area covered by water hyacinth," Indian Jour. Env. Prot., 19(10), 103-107. 1989.

[18] Ghaly, A.E., M. Kamal, Mahmoud N.S, "Phytoremediation of aquaculture wastewater for water recycling and production of fish feed," Environmental technology, 14(10), 1011-1016. 2004.

[19] Groudev, S.N., Nicolova, M.V., Spasova I.I., Komnitsas K., Paspaliaris I., Treatment of acid mine drainage from a uranium deposit by means of a natural wetland. Paper presented at the ISEB Phytoremediation Conference, Leipzig, Germany: pp. 146148. 2001.

[20] Wirojanagud, W. Supachaisakorn, N., Boonpoke A., Removal of organic matter contaminated pulp and paper industrial wastewater by soil, $17^{\text {th }}$ WCSS, Thailand, 14-21. 2002.

[21] Santos, E.J., Silva, E.H.B.C., Fiuza, J.M., Batista, T.R.O., “A high organic load stabilization pond using water hyacinth- A Bahia experience,” Water Sci. Tech. 19(10): pp 25-28. 1987.
[22] Conley, L.C., Dick, R.I. and Lion, L.W., "An assessment of the root zone method of wastewater treatment," Research Journal of Water Pollution Control Federation, (63), 239-247. 1991.

[23] Tegegne, B.M., J.J.A. Hans van Bruggen, J. O’Keeffe, S.W. Wasala. A Constructed Wetland for Wastewater Treatment Emphasis on Optimization of Nitrogen Removal, UNESCO-IHE Institute for water education. Watermill Working Paper Series, 2427. 2008.

[24] Tripathi, B. D. and Shukla, S. C., "Biological treatment of wastewater by selected aquatic plants," Environmental Pollution (69), 69- 78. 1991.

[25] Adeola, S., Michael Revitt, Brian Shutes, Hemda Garelick, Huw Jones, Clive Jones. "Constructed wetland control of BOD levels in airport runoff,” International Journal of Phytoremediation, 11(1), 1-10. 2009.

[26] Sharma, N. and Sharma, S. "Combined paper mill effluent treatment by water hyacinth,” Indian Jour. of Environ.Prot., 14(9), 678-681. 1994.

[27] Zimmels, Y., Kirzhner, F., Malkovskaja, A. "Application of Eichhornia crassipes and Pistia stratiotes for treatment of urban sewage in Israel,” Journal of environmental management, 81(4), 420-428. 2006.

[28] Zhang, X., Peng, L.I.U., Yue-suo Yang and Wen-ren Chen. "Phytoremediation of urban wastewater by model wetlands with ornamental hydrophytes," Journal of Environmental Sciences, 19(8), 902-909. 2007.

[29] Bell, J. and C.A. Buckley. "Treatment of textile dye using anaerobic baffled reactor,” Water, 29 (2), 432-437. 2003.

[30] Haris, M. Study on the performance of Anaerobic Baffled Reactor (ABR) unit in Sanimas Program in Mojokerto, Final Project. Department of Environmental Engineering, ITS, Surabaya, 134147. 2007.

[31] Maehlum, T. and Jensse, P.D. Norway. In Constructed wetlands for wastewater treatment in Europe. (Eds: Vymazal J., Brix, H., Cooper, P.F., Green, M.B., Haberl, R.). Backhuys publication. Leiden, 217-225. 1998.

[32] Vymazal, J., "Removal of BOD5 in constructed wetlands with horizontal sub-surface flow: Czech experience,” Water Science \& Technology, 40(3), 133-138. 1999.

[33] Hartman, M.C., Eldowney W., Pollution: Ecology and biotechnology, John Wiley and sons Inc. New York, 174-189, 1993.

[34] Reddy, K.R. and Debusk, T.A. "Utilization of aquatic plants in water pollution control”, Water Sci. Tech., 19(10), 61-79, 1987.

[35] Dipu, S., Anju A., Kumar, Salom Gnana Thanga V., "Phytoremediation of dairy effluent by constructed wetland technology,” Environmentalist, 31 (3), 263-268. 2011. 